Marcelina de Zoete-Leśniczak ${ }^{*}$

\section{Sōseki w kontekstach}

DOI: http://dx.doi.org/10.12775/LC.2017.071

W krẹgu Kokoro

O literackich i pozaliterackich kontekstach Sedna rzeczy Natsumego Sōsekiego

Redlakcja:

Iwona Koruziniska-Nawrocka

Katarzyna Sonnentery

Aleksandra Szczechla

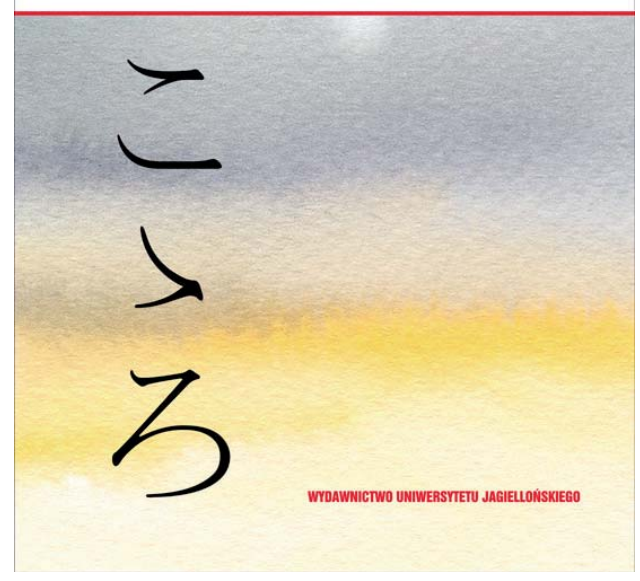

becny 2017 rok zamyka okres czterech lat obchodów związanych $\mathrm{z}$ osobą jednego z najwybitniejszych japońskich mistrzów pióra, jakim niewątpliwie był Natsume Sōseki. Otóż na 2017 rok przypada 150 lat od urodzin pisarza, rok miniony - 2016 upamiętnił jego setną rocznicę śmierci,

* Adiunkt w Zakładzie Japonistyki Uniwersytetu Mikołaja Kopernika w Toruniu; autorka prac na temat twórczości Tanizakiego Jun'ichirō, teatru japońskiego przełomu XIX i XX wieku oraz powojennej i współczesnej prozy japońskiej. E-mail: marushka@umk.pl. a rok 2014 stał się okazją do świętowania 100 lat od wydania w Japonii powieści Kokoro こころ z najbardziej znanych, najpoczytniejszych i uważanych przy tym za najdojrzalsze opus magnum w dorobku artystycznym pisarza. Takie nagromadzenie jubileuszy stało się w Japonii okazją do uczczenia osoby pisarza przez organizowanie poświęconych mu wystaw, wykładów czy paneli literaturoznawczych. Warto chociażby wspomnieć otwarte w grudniu 2016 roku trzydniowe sympozjum na Żeńskim Uniwersytecie Ferrisa (Ferrisu Jogakuin Daigaku) w Jokohamie, poświęcone dwóm zagadnieniom: postrzeganiu świata przez Sōsekiego oraz recepcji jego literatury przez czytelników na świecie. Sympozjum to - firmowane nazwiskiem współcześnie najznamienitszego badacza twórczości Sōsekiego, profesora Uniwersytetu Tokijskiego (Tōkyō Daigaku) Komoriego Yōichiego ${ }^{2}$, oraz goszczące międzynarodowe tuzy literaturoznawców japońskich - było niewątpliwie wielkim i spektakularnym wydarzeniem naukowym ${ }^{3}$.

W Polsce początek badań spuścizny literackiej Sōsekiego przypada na lata siedemdziesiąte, gdy pojawiły się pierwsze prze-

1 Z jap. uczucia, wnętrze, serce, sedno, psychika, charakter, ukryte myśli, wiedza.

2 Komori Yōichi jest autorem licznych monografii literaturoznawczych, a z tych poświęconych właśnie Sōsekiemu najbardziej znane są na przykład Sōseki o yominaosu (Czytając jeszcze raz Sōsekiego), Tokio 2016; Sōseki ron. 21 seiki o ikinuku tameni (Teoria Sōsekiego - jak przetrwać w XXI wieku), Tōkyō 2010; inni wybitni, japońscy badacze Sōsekiego to między innymi: Ishihara Chiaki, Karatani Kōjin czy lida Yūko (notabene najważniejsza obecnie badaczka gender w Japonii).

3 Szczegółowe informacje i progam tego sympozjum znajdują się na jego stronie internetowej. Niestety organizatorzy nie podają tam żadnych danych odnośnie do publikacji posympozjalnej. Por. Dai jukkai nihon bungaku kokusai kaigi. Natsume Sōseki Kokusai Shinpojiumu, http://www.ferris.ac.jp/information/ approach/educational-reform/2016symposium_ ns.html [dostęp: 29.07.2017]. 
kłady dwóch jego powieści - w 1973 roku Kokoro ${ }^{4}$, zaś cztery lata później Wagahai wa neko de aru (Jestem kotem) - w przekładzie najwybitniejszego polskiego znawcy i tłumacza literatury japońskiej Mikołaja Melanowicza. Od tamtej pory, czyli przez nieco ponad czterdzieści lat, Sōseki jest obecny w polskim dyskursie japonistycznym. Oprócz tłumaczeń jego literatury i artykułów naukowych poświęconych jego pisarstwu polska japonistyka może poszczycić się dwoma wydarzeniami, które - choć oddalone od siebie w czasie o około dziesięć lat - potwierdzają nieustanne i żywe zainteresowanie japonistów twórczością Sōsekiego, która stanowi inspirację do badawczych poszukiwań, obierania nowych szlaków interpretacyjnych czy prób odczytywania jego prozy z perspektywy człowieka XXI wieku. Pierwsze z nich to sympozjum, które odbyło się w grudniu 2005 roku w Poznaniu w tamtejszej Katedrze Orientalistyki Uniwersytetu im. Adama Mickiewicza z okazji setnej rocznicy powstania powieści Jestem kotem. Wydarzenie zainicjowała wybitna „sōsekistka” - badaczka i tłumaczka pisarza Monika Tsuda. Oprócz ciekawych i wartościowych wystąpień polskich badaczy, całości dodała splendoru obecność gościa specjalnego - profesor Yoko Matsuoki McClain ${ }^{6}$ (1924-2011), prywatnie wnuczki Sōsekiego. Efekty tego spotkania zostały zebrane i opublikowane w dwóch numerach czasopisma naukowego „Silva Iaponicarum” wydawanego przez Wydawnictwo Naukowe UAM. Zeszyt nr 7 zawiera w całości teksty referatów wygłoszonych podczas sympozjum (tematyka

\footnotetext{
4 S. Natsume, Sedno rzeczy, tłum. M. Melanowicz, Warszawa 1973.

5 Idem, Jestem kotem, tłum. M. Melanowicz, Warszawa 1977.

6 Węcej na temat biografii Yoko Matsuoki McClain zob. M. Szychulska (primo voto Tsuda), Between East and West: A Profile of Professor Yoko McClain, "Silva laponicarum" 2006, nr 9, s. 11-15.
}

związana ściśle z powieścią Jestem kotem $)^{7}$, a zeszyt nr 9 wypełniły zapisy wykładów i wspomnień wnuczki pisarza o charakterze stricte biograficznym, oscylujące wokól tematyki życia prywatnego Sōsekiego - jako dziadka - bądź wokół osoby jego małżonki Kyōko ${ }^{8}$.

Kolejnym wydarzeniem, stosunkowo niedawnym, było zorganizowane na Uniwersytecie Warszawskim 30 września 2015 roku sympozjum z okazji setnej rocznicy wydania w Japonii powieści Kokoro, w całości jej dedykowane ${ }^{9}$. Pokłosiem tego spotkania japonistów różnych specjalizacji, poczynając od honorowego gościa sympozjum - profesora Mikołaja Melanowicza, jest wydana $\mathrm{w}$ minionym kwartale bieżącego roku publikacja zatytułowana $W$ kręgu „Kokoro”. O literackich i pozaliterackich kontekstach "Sedna rzeczy” Natsumego Sōsekiego $o^{10}$. Jest to bardzo ważna pozycja wydawnicza, warta uwagi i istotna z perspektywy rozwoju dalszych polskich badań japonistycznych w zakresie literatury. Ze względu na zaproponowane przez autorów-japoni-

7 W tomie znalazły się następujące artykuły: M. Kanert, "I Am a Cat". From A Historician's Perspective; Y. Matsuoka-McClain, Natsume Sōseki (1867-1916) and His First Novel "I Am a Cat"; M. Melanowicz, "Wagahai wa neko de aru"- Narrator's eyes and ears; M. Szychulska,

『吾輩は猫である』と『三四郎』に見る夏目漱石 の作品のアクチュアリティー (Aktualność utworów Natsumego Sōsekiego w "Jestem kotem" $i$ "Sanshirō"); por. "Silva laponicarum" 2006, nr 7.

8 W tomie znalazły się artykuły: M. Szychulska, Between East and West: A Profile of Professor Yoko McClain; Y. Matsuoka-McClain, Natsume Sōseki and Jane Austin; Y. Matsuoka-McClain，孫娘から見た 漱石漱石 (Natsume Sōseki widziany oczyma wnuczki); Y. Matsuoka-McClain，漱石そして鏡子夫人につ いて (O Sōsekim i jego małżonce Kyōko); por. „Silva laponicarum" 2006, nr 9.

9 Program sympozjum znajduje się pod adresem: http://psbj.orient.uw.edu.pl/wp-content/uploads/2017/06/Program-sympozjum-PSBJ-2015.pdf [dostęp 29.07.2017].

10 W kręgu "Kokoro". O literackich i pozaliterackich kontekstach "Sedna rzeczy" Natsumego Sōsekiego, red. I. Kordzińska-Nawrocka, K. Sonnenberg, A. Szczechla, Kraków 2017. 
stów konteksty odczytań tekstu powieści Kokoro - zdecydowanie wykraczające poza wyizolowany obszar wyłącznie japonistyczny - może z powodzeniem na dłużej przykuć uwagę odbiorców: czy to potencjalnych czytelników, czy literaturoznawców nie-japonistów, którzy dopiero zaczynają poznawać literaturę japońską. O czym jednak dokładnie traktuje ten tom i dlaczego warto się nad nim pochylić? Czy po jego lekturze (notabene już na wstępie wypada zaznaczyć, że zgromadzone $\mathrm{w}$ nim teksty są materiałem wymagającym od czytelnika wytrwałości, uważności i podstawowej wiedzy z zakresu literaturoznawstwa i językoznawstwa niekoniecznie japońskiego) odbiorca może stać się bardziej świadomy i uwrażliwiony na pewne aspekty i cechy dystynktywne prozy już nie tyle samego Sōsekiego, ale ogólnie prozy japońskiej, sprawiające, że na tle innych literatur świata wypada ona atrakcyjnie i intrygująco? Zanim spróbuję odpowiedzieć na to pytanie, chciałabym przedstawić pokrótce charakterystykę omawianego obiectum quaestionis.

Monografię otwiera wstęp autorstwa Iwony Kordzińskiej-Nawrockiej, Katarzyny Sonnenberg i Aleksandry Szczechli zatytułowany Wstęp. W kręgu "Kokoro”. Autorki w zwarty i syntetyczny sposób objaśniają okoliczności napisania powieści Kokoro i podają krótkie dane biograficzne dotyczące Sōsekiego w okresie jego prac nad powieścią. Co więcej, przedstawiają szkicowo historię dyskursu literaturoznawczego poświęconego Sednu rzeczy w Japonii, a także podają okoliczności powstania całego zbioru. Jak podkreślają redaktorki, jako cel swych prac obrały one „zaprezentowanie studiów nad wybranymi aspektami twórczości Sōsekiego, które nie były dotąd eksponowane $\mathrm{w}$ teoretycznoliterackich i językoznawczych dyskusjach poświęconych Kokoro, a które takie dyskusje niewątpliwie wzbogacają i pogłębiają" (s. 9).
Oprócz tego sygnalizują tematykę każdego z wchodzących w skład monografii artykułów, wskazując na konteksty, w jakich autorzy analizują teksty Sōsekiego. Już na wstępie autorki jasno określają charakter tomu, konkretyzując, że „zostały [tu] zebrane refleksje polskich japonistów na temat twórczości Sōsekiego - od czasów powstania Bokusetsuroku do chwili opublikowania Kokoro" (s. 9).

$\mathrm{W}$ istocie, taki też właśnie - chronologiczny i logicznie uporządkowany - jest układ artykułów w recenzowanym tomie. Pomaga on bowiem linearnie prześledzić nieznane dotąd polskiemu czytelnikowi wątki z jakże nieszablonowej biografii Sōsekiego, ułatwiając tym samym zrozumienie przedstawionych kontekstów i możliwości odczytań prozy mistrza. I tak, na początku ukazany jest on jako twórca poszukujący i dopiero kształtujący swą wrażliwość artystyczną, a następnie odbywający podróże do różnych miejsc (także te duchowe) celem znalezienia inspiracji, materiału literackiego czy skonfrontowania posiadanej teorii z praktyką (na przykład wyjazd do Wielkiej Brytanii). Całość zamyka prezentacja refleksji twórcy już świadomego, krytycznego względem siebie, źródeł inspiracji czy środowiska, w jakim tworzy.

Tom otwiera wywiad $\mathrm{z}$ Mikołajem Melanowiczem - tłumaczem-wirtuozem tekstów kanonicznych literatury japońskiej XX wieku. Dzięki dobrze przemyślanym przez prowadzące wywiad - Katarzynę Sonnenberg i Aleksandrę Szczechlę - pytaniom czytelnik otrzymuje niezwykle cenną - niczym na wagę złota - garść informacji, których trudno by przecież gdziekolwiek szukać, gdyż w dyskursie przekładoznawczym niewiele miejsca poświęca się osobistym retrospekcjom tłumacza, okolicznościom jego pracy czy nierzadko źle układającej się współpracy $\mathrm{z}$ wymagającym - acz można zaryzykować stwierdze- 
nie - roszczeniowym i autorytatywnym wydawcą, o jakim Melanowicz wspomina. Na szczególną uwagę zasługuje sensowny zabieg (być może umyślnie zastosowany) umiejscowienia osoby Melanowicza jako klamry otwierającej i zamykającej monografię. Zbiór rozpoczyna się bowiem wspomnieniami tłumacza powieści Kokoro, kończy natomiast jego rozważaniami poświęconymi miejscu tego dzieła we współczesnym dyskursie literaturoznawczym w Japonii XXI wieku.

Kolejny artykuł zatytułowany Sōseki no kanbun nikki "Bokusetsuroku” no jobun o yomu 漱石の漢文日記『木屃録』の 序文を読む (Czytając wstęp do „Notatek $z$ trocin” Sōsekiego), napisany w całości w języku japońskim, przedstawia wstęp do dziennika podróży napisanego w 1889 roku, ujawniając tym samym kontekst chiński w początkowej fazie pisarstwa mistrza. Autorka przekłada w nim na współczesny język japoński fragmenty dziennika napisane w klasycznym języku japońskim. Artykuł ten należałoby ocenić krytycznie z dwóch perspektyw. Po pierwsze jest on jedyną pozycją $\mathrm{w}$ całej monografii napisaną $\mathrm{w}$ całości po japońsku, a więc przeznaczoną dla odbiorcy będącego bądź natywnym użytkownikiem japońszczyzny, bądź czytelnikiem (najpewniej japonistą) posługującym się sprawnie językiem japońskim w mowie i piśmie. $\mathrm{W}$ tej sytuacji umieszczenie go w tomie jako jedynego pośród tekstów w języku polskim ogranicza niejako jego przeznaczenie, zawężając tym samym grono jego odbiorców do tych, którzy potrafią posługiwać się japońszczyzną, nawet w jej klasycznym wariancie. Efekt byłby zupełnie inny, a i artykuł ze zrozumieniem przeczytałoby więcej osób, gdyby oprócz tłumaczenia Notatek z trocin z klasycznego języka japońskiego na współczesny zadbano również o dodanie tłumaczenia całości (czyli oprócz tekstu oryginalnego także niezwykle treści- wych i pomocnych w interpretacji utworu komentarzy autorki artykułu) na język polski. Po drugie, sam artykuł jest o tyle ważny, że przybliża czytelnikowi (z zaznaczeniem: posługującemu się językiem japońskim) okres fascynacji językiem chińskim, poezją i sztuką chińską i pod wpływem tegoż dokonywanych przez Sōsekiego nieśmiałych prób pisarskich. To właśnie na kartach Notatnika $z$ trocin kształtował się początkowy styl literacki pisarza poszukującego formy literackiego przedstawiania (na przykład przyrody). Autorka opierając się na tekście Notatnika..., wyjaśnia okoliczności powstania tego utworu, a przez przytoczenie miejsca - Kamakury (o której drobiazgowo pisze Adam Bednarczyk) wykazuje związki z powieścią Kokoro. Objaśnia także semiotykę tytułu dziennika podróży. Na szczególną uwagę zasługują wspomniane już komentarze do tłumaczonych fragmentów, ale także - co jest raczej rzadko stosowanym zabiegiem w tego typu publikacjach - komentarze i wyjaśnienia towarzyszące zebranej przez autorkę bibliografii.

Sōseki podróżujący jest również przedstawiony w kolejnym artykule pt. $W$ londyńskiej mgle, zironia i dystansem - „Muzeum Carlyle'a” Natsume Sōsekiego, autorstwa Aleksandry Szczechli. Tekst odnosząc się do opowiadania Sōsekiego pt. Kārairu Hakubutsukan (Muzeum Carlyle'a), nawiązuje do wątku londyńskiego w biografii pisarza, kiedy to Sōseki został oddelegowany przez Ministerstwo Edukacji Japonii do odbycia podróży studyjnej po Wielkiej Brytanii w latach 1901-1903. Szczechla na wstępie w bardzo wyczerpujący i zwarty sposób przedstawia okoliczności wyjazdu pisarza, uzupełniając wszystko wiadomościami o utworach, jakie wtedy pisał, ale przede wszystkim - informacjami o autorach zachodnich, jakimi się wówczas inspirował. Na przykładzie zręcznie i fachowo przetłumaczonych przez siebie fragmentów 
opowiadania wyjaśnia także genezę inspirowanych pobytem $\mathrm{w}$ Londynie eksperymentów Natsumego z ironią - zabieg ten stanie się znakiem rozpoznawczym autora w utworach pochodzących z najdojrzalszego okresu jego twórczości. Szczechla bardzo interesująco prowadzi swój wywód, dekonstruując opowiadanie pod względem treści, ale także dociekając przyczyn zdystansowanego stosunku pisarza do tytułowego Carlyle'a i stosowanych w opowiadaniu technik posługiwania się ironią. Wymowa tekstu badaczki zdecydowanie wykracza poza przedstawione tu opowiadanie, gdyż zaproponowane przez nią wskazówki interpretacji czy odczytania kontekstu mogą być $\mathrm{z}$ powodzeniem stosowane podczas lektury lub analizy innych dzieł pisarza.

Do innego muzeum, mianowicie galerii obrazów malowanych słowem, zabiera czytelników Katarzyna Sonnenberg - autorka kolejnego artykułu zatytułowanego $O$ granicach poezji i malarstwa $w$ "Kusamakura” (Poduszka $z$ traw) Natsumego Sōsekiego. Tekst Sonnenberg przedstawia dzieło „uważane za jedno z najbardziej poetyckich" (s. 55) - jak dowiadujemy się na wstępie. Następnie autorka wprowadza czytelnika do Laokoona Lessinga, gdyż to wokół tego dzieła oscylują zawarte w Kusamakurze krytyczne analizy toretycznoliterackie Sōsekiego-narratora - pisarza poszukującego i szlifującego swój warsztat pisarski. Tworząc teorię i wizję własnej literatury, Natsume nierzadko pozostawał pod wplywem twórców zachodnich. Ale potrafil być też wobec nich krytyczny. Taki właśnie mają wydźwięk spostrzeżenia ujawnione w Kusamakurze, dotyczące szkicowania natury słowem i obrazem, zestawione z przedstawioną przez Lessinga w Laokoonie wizją sztuki i literatury. Artykuł uświetniają dokonane przez autorkę znakomite pasaże tłumaczeń Kusamakury, wybitnie oddające estetykę prozy Sōsekiego.
Nullum magnum ingenium sine mixtura dementiae fuit, czyli „Nie było wielkiego geniusza bez domieszki szaleństwa” - to słowa w pełni oddające tematykę kolejnego przedstawionego w krakowskiej monografii tekstu autorstwa Moniki Tsudy zatytułowanego Geniusz i szaleństwo - patografia pierwszych powieści Sōsekiego. Badaczka dociekliwie przypatruje się wczesnemu okresowi życia i twórczości Sōsekiego pod kątem występowania u niego pierwszych oznak szaleństwa i najmniejszych przejawów zaburzeń psychicznych. W centrum jej rozważań pozostaje Wagahai wa neko de aru i właśnie ta powieść stanowi główny materiał źródłowy dla prześledzenia w niej pierwiastków szaleństwa. Z artykułu Tsudy jednoznacznie wynika, że autor był świadom kruchości swej psychiki i nie czuł się z tym odosobniony. Nie krył też tego, lekkim szaleństwem obdarzając bohaterów swych utworów, także w późniejszym okresie twórczości.

$\mathrm{Na}$ wycieczkę do wspomnianej już Kamakury - podtokijskiej mekki wielbicieli uzdrowisk i nadmorskich kurortów zabiera czytelnika w swoim tekście Adam Bednarczyk. Autor celnie odczytując „tokijskość" twórczości Natsumego i obecność Kamakury w jego utworach, funduje czytelnikom niezwykle ciekawie opracowany spacer po wspomnianym miejscu, wpisując się tym samym w jakże popularne ostatnimi laty w dyskursie światowym spojrzenie geopoetyczne na tekst, czyli zagłębienie się w materiał literacki z perspektywy wzajemnego oddziaływania na siebie literatury i przestrzeni geograficznej ${ }^{11}$. Wycieczka Bednarczyka jest wsparta imponującą ilością misternie i perfekcyjnie dopracowanych przypisów, które nie tyle uzupełniają podane w głównym tekście informacje, co

11 Na temat geopoetyki zob. E. Rybicka, Geopoetyka. Przestrzeń i miejsce we współczesnych teoriach i praktykach literackich, Kraków 2014. 
niczym znaki topograficzne uprzyjemniają wędrówkę po tym obszarze literatury Sōsekiego. Na koniec po tej długiej i wymagającej podróży badacz raczy czytelnika dość nieszablonową formą zakończenia artykułu naukowego (o czym dowcipnie informuje w tytule swego zakończenia), a mianowicie rozwiązuje zagadkę imienia Sōseki. Tu znów pojawia się kontekst chiński - tym razem już bezpośrednio związany z pseudonimem pisarza (jego prawdziwe imię to Kinnosuke). Artykuł ten jest ostatnim stricte literaturoznawczym w tym tomie, gdyż następujące bezpośrednio po nim trzy teksty to efekty działań trzech wybitnych specjalistów językoznawstwa japońskiego, którzy postanowili przyłączyć się do tematu wiodącego monografii, a więc powieści Kokoro i towarzyszących jej kontekstów, mając naprawdę wiele intrygujących i arcyciekawych treści do zaoferowania czytelnikowi.

Lingwistyczny tryptyk otwiera wysoce specjalistyczny tekst Romualda Huszczy zatytułowany Lingwistyczna poetyka narracji $w$ „Kokoro”. Autor przygląda się w nim różnym aspektom narracji we wspomnianej powieści, wyjaśnia też drobiazgowo jej gramatyczne własności oraz artystyczne walory opowiadania w niej zdarzeń. Wskazuje na dwa odrębne style narracji - ściśle narratywny i epistolarny, a wszystko to uzupełnia cennymi komentarzami dotyczącymi wybranych aspektów ewolucji języka japońskiej prozy ostatnich 300 lat. Wykazuje też wpływ, jaki miało na rozwój japońskiej prozy jej zderzenie $\mathrm{z}$ przedstawioną $\mathrm{w}$ Japonii literaturą tłumaczeniową dzieł zachodnich. Tekst Huszczy - jakkolwiek trudny w odbiorze ze względu na nagromadzenie $\mathrm{w}$ nim słownictwa wysoce specjalistycznego z dziedziny językoznawstwa japońskiego - jest niewątpliwie nowatorski, chociażby w zakresie samego badawczego podejścia do Kokoro, a więc skupieniu się w całości na stylu narracji, która jako obiekt badań wyda- je się nieco przez literaturoznawców zaniedbywana.

Kolejną językoznawczą „gratką” $\mathrm{w}$ omawianym tomie jest niezwykle spójny, wartki w lekturze i przykuwający uwagę tekst Jarosława A. Pietrowa, mianowicie "Kokoro" - literacka semiotyka tytutu powieści. Autor niczym detektyw przystępuje do rozwiązania zagadki tytułu utworu pod kątem pełnionej przez niego roli, sposobów odczytania i tego, jak mogą one wpłynąć na recepcję powieści przez czytelnika. Wychodząc od definicji słowa „tytul”, poprzez podanie kilkunastu przykładów tłumaczeń tytułu Kokoro na języki obce, Pietrow sonduje, jaką funkcję może ów tytuł powieści pełnić i jak można go powiązać z fabułą utworu. Dokonuje też imponującej prezentacji pól znaczeniowych japońskiego rzeczownika kokoroこころ / 心 / つろ, podając już konkretne przykłady użycia go w kontekście powieści Sōsekiego. Warto zwrócić szczególną uwagę na fakt, że Pietrow wszędzie tam, gdzie podaje zwroty japońskie (jak na przykład wspomniane powyżej definicje znaczeń rzeczownika kokoro), podaje także polskie ich tłumaczenie. To czyni jego wywód jeszcze bardziej zrozumiałym i przystępnym w odbiorze z punktu widzenia czytelnika nieposługującego się językiem japońskim.

Tryptyk zamyka artykuł Bartosza T. Wojciechowskiego zatytułowany Asymetrie jezzykowe $w$ przekładach "Kokoro”. Autor z perspektywy językoznawczej, ale jak sam uściśla - głównie translatorycznej - poddaje analizie fragmenty przekładów Sedna rzeczy na różne języki: polski, angielski i rosyjski. Ponadto czytelnik otrzymuje wspomniane fragmenty tekstu tłumaczenia powieści $\mathrm{w}$ wersji ekskluzywnej, gdyż zaopatrzonej dodatkowo $\mathrm{w}$ niezwykle interesujące komentarze językoznawcze. Eksploracje tekstu dokonywane przez Wojciechowskiego ujawniają liczne 
asymetrie wśród omawianych tłumaczeń. Wskazują też niuanse, miejsca pozornie nieprzetłumaczalne, czasem brak odpowiednich ekwiwalentów, czyli wszystko to, z czym zmagać musi się tłumacz języków różnych i odległych tak kulturowo, jak strukturalnie - w tym wypadku opozycja dotyczy grupy: polski, angielski, rosyjski a japoński. Wojciechowski z uwagą przedstawia wybrane przez siebie specyficzne pojęcia kulturowe, wyrażenia idiomatyczne i behawitywy czy poziomy honoryfikatywne. Nie podaje jednak gotowej recepty na tłumaczenie - jego przemyślenia mają jedynie charakter niezwykle ważnych glos na temat tekstu już przetłumaczonego i mogą okazać się niezwykle przydatne każdemu, kto swą przygodę z tłumaczeniem tekstów japońskich - nowożytnych bądź współczesnych - dopiero rozpoczyna. Ze względu na sposób prowadzenia narracji wywodu, który jest niezwykle spójny i przejrzysty, mimo nagromadzonych wyrażeń specjalistycznych z zakresu językoznawstwa japońskiego, artykuł Wojciechowskiego może być również niezwykle pomocny jako punkt referencyjny na zajęciach $\mathrm{z}$ translatoryki tekstów literatury japońskiej. Stanowi on też niezwykle kuszące zaproszenie do zgłębienia warsztatu tłumacza.

Całość tomu - o czym wspomniano na początku - zamyka niezrównanie ważny z punktu widzenia badań literatury japońskiej w Polsce głos - Mikołaj Melanowicz ze swoim artykułem Kilka refleksji w zwiazkuze stuleciem obecności „Kokoro” $w$ dyskursie literackim. Przyznaje on już na wstępie, że jako literaturoznawca miał okazję debiutować w czasach, gdy wśród badaczy prym wiódł strukturalizm, teraz jednak profesor jest zaintrygowany tekstem w kontekście, czyli wsłuchiwaniem się w głos powieści, która wskazuje konteksty do analizy. Profesor naświetla w skrócie stan badań nad Kokoro Sōsekiego w japońskim dyskursie literaturo- znawczym, ale także wzmiankuje o miejscu tej powieści we współczesnej kulturze japońskiej. Podaje też najwybitniejsze nazwiska japońskich badaczy Kokoro i zestawia krótko obierane przez nich metody badawcze oraz proponowane konteksty odczytań tej powieści. Wśród nich najbardziej może interesować zakładająca homoerotyczny charakter znajomości głównych bohaterów Kokoro teza Yoshimoto Takaakiego - jednego z najważniejszych badaczy powieści $\mathrm{w}$ Japonii ${ }^{12}$.

Tak w zarysie można przedstawić treść pierwszej $\mathrm{w}$ historii polskiej japonistyki monografii w całości poświęconej jednej z najsławniejszych japońskich powieści XX wieku - Kokoro Natsumego Sōsekiego. Autorzy artykułów zaprezentowanych w tomie zdecydowali się na nowatorski i aktualnie popularny sposób odczytywania literatury jako tekstu w kontekście. Prezentując różne konteksty, a także sięgając do analizy utworów nieznanych dotąd polskiemu czytelnikowi Sōsekiego, co więcej tłumacząc fragmenty tych dzieł, wypełnili wielką lukę na polu dotychczasowych badań literatury tego wspaniałego twórcy, nierzadko nazywanego przez samych Japończyków ich pisarzem narodowym. Już po pobieżnym oglądzie spisu treści wiadomo, że w tomie tym najważniejszy jest tekst, słowo pisane, literatura i wszystko to, co za sobą niosą. Ten zbiór traktuje biografię pisarza jedynie jako uzupełnienie w procesie odczytywania kontekstowego jego literatury. Teksty zanurzone są tutaj jakby w kontekstach, a nie biografii autora, jak do tej pory najczęściej bywało w polskim dyskursie poświęconym twórczości Sōsekiego. Autorzy odświeżyli pamięć o pisarzu, a przede wszystkim, poprzez wybór, przekład, drobiazgową analizę

12 O homoerotyzmie pisze także Karatani Kōjin, wybitny badacz prozy Sōsekiego metodami wyrosłymi na fundamencie strukturalistycznym; zob. K. Karatani, Kotoba to higeki, Tōkyō 1993, s. 51-52. 
oraz umieszczenie $\mathrm{w}$ odpowiednim kontekście utworów nieznanych do tej pory w Polsce, jakby „wpompowali” w te utwory nową krew, pozwalając im tym samym narodzić się na nowo - tym razem w nowych kontekstach. Język prozy Natsumego jest żywy w tym tomie. Sam pisarz natomiast jawi się jako artysta poszukujący, stale konfrontujący swą wiedzę z zakresu teorii literatury i nieustannie ewoluujący. Układ artykułów bez problemu pozwala tę ewolucję dostrzec i prześledzić. Dobór tekstów natomiast dotyka najważniejszych wątków biografii artysty, jak: trud tworzenia, wyobcowanie jednostki i cierpienie (pobyt w Wielkiej Brytanii), poszukiwanie inspiracji $\mathrm{w}$ przyrodzie, $\mathrm{z}$ dala od tokijskiego zgiełku. Przedstawione teksty - jak szkiełka - układają się niejako w mozaikę, której elementem spajającym całość jest biografia Sōsekiego, a w niektórych przypadkach także powieść Kokoro. Nie trzeba znać całej twórczości Natsumego, by na podstawie tych tekstów uzyskać wyraźny obraz pisarza i jego literatury.

Należy żywić nadzieję, że teksty zawarte $w$ monografii trafią do szerszego grona odbiorców, aniżeli tylko wąskiej grupy japonistów czy adeptów języka japońskiego i ogólnie rozumianej kultury Japonii. Oferują one bowiem dużo ciekawych i ważnych informacji przydatnych w lekturze czy interpretowaniu literatury nie tylko japońskiej, ale i światowej. Proponowane tu kon- teksty odczytywania prozy Sōsekiego mogą być przecież rozszerzane o inne konteksty, co może tylko zaowocować ciekawymi interpretacjami i badaniami literaturoznawczymi. Monografia ze względu na zaproponowane $\mathrm{w}$ niej nowe odczytania literatury Nastumego celnie wpisuje się $\mathrm{w}$ ramy aktualnego dyskursu (co ważne - międzynarodowego!) sposobów interpretacji prozy Natsumego w XXI wieku. Potwierdzają to dwa główne tematy cytowanego już tutaj we wstępie, jedynego jak do tej pory zorganizowanego w ramach ostatniego cyklu rocznic Sōsekiego międzynarodowego sympozjum literaturoznawczego: „Jak Sōseki postrzegał świat?” oraz „Jak odczytywana jest literatura Sōsekiego na świecie?".

Monografia krakowska być może doczeka się swej wersji anglojęzycznej, bo niewątpliwie warto, by zebrane tutaj teksty mogły ubogacić współczesny międzynarodowy dyskurs dotyczący literatury Natsumego Sōsekiego. Nie jest to lektura łatwa i raczej celuje w czytelnika wymagającego, ale przecież o takiego właśnie wytrzymałego odbiorcę, któremu proza przyniesie ukojenie, pisarzowi chodziło.

W kręgu "Kokoro". O literackich i pozaliterackich kontekstach "Sedna rzeczy" Natsumego Sōsekiego, red. Iwona Kordzińska-Nawrocka, Katarzyna Sonnenberg, Aleksandra Szczechla, Wydawnictwo Uniwersytetu Jagiellońskiego, Kraków 2017, ss. 179. 